\title{
HISTORY OF INDIAN TRADITIONAL MEDICINE: A MEDICAL INHERITANCE
}

\author{
PARTHA PRADIP ADHIKARI ${ }^{1,2 *}$, SATYA BHUSAN PAUL ${ }^{2}$
}

${ }^{1}$ Genoine Research Laboratory Pvt. Ltd., Subhash Nagar, Karimganj, Assam, India. ${ }^{2}$ Department of Chemistry, Assam University, Silchar, Assam, India. Email: dr.parthaadhikari@gmail.com

Received: 09 August 2017, Revised and Accepted: 27 October 2017

ABSTRACT

Objective: Indian Traditional Medicine, the foundation of age-old practice of medicine in the world, has played an essential role in human health care service and welfare from its inception. Likewise, all traditional medicines are of its own regional effects and dominant in the West Asian nations; India, Pakistan, Tibet, and so forth, East Asian nations; China, Korea, Japan, Vietnam, and so forth, Africa, South and Central America. This article is an attempt to illuminate Indian traditional medical service and its importance, based on recent methodical reviews.

Methods: Web search engines for example; Google, Science Direct and Google Scholar were employed for reviews as well as for meta-analysis.

Results: There is a long running debate between individuals, who utilize Indian Traditional Medicines for different ailments and disorders, and the individuals who depend on the present day; modern medicine for cure. The civil argument between modern medicine and traditional medicines comes down to a basic truth; each person, regardless of education or sickness, ought to be educated about the actualities concerning their illness and the associated side effects of medicines. Therapeutic knowledge of Indian traditional medicine has propelled various traditional approaches with similar or different theories and methodologies, which are of regional significance.

Conclusion: To extend research exercises on Indian Traditional Medicine, in near future, and to explore the phytochemicals; the current review will help the investigators involved in traditional medicinal pursuit.

Keywords: Indian traditional medicine, Age-old practice, Phytochemicals.

(C) 2018 The Authors. Published by Innovare Academic Sciences Pvt Ltd. This is an open access article under the CC BY license (http://creativecommons. org/licenses/by/4. 0/) DOI: http://dx.doi.org/10.22159/ajpcr.2018.v11i1.21893

\section{INTRODUCTION}

Natural products (NPs) signify large and diverse secondary metabolites with a comprehensive choice of biological activities those have established with their numerous practices, particularly in human and veterinary and also in agriculture [1-3]. NPs are derived from microorganisms, marine animals, and also from plant sources. The plant-derived NPs are the products of secondary metabolism; the compounds which are not essential for existence in laboratory conditions but are certainly responsible for self-defense coordination in natural conditions. Macromolecules such as DNA, RNA, protein, and precursors, and their essential intermediates found naturally are not included in the definition of NPs.

Pharmaceutical, insecticidal, and herbicidal importance have been driven form NP discovery and been taken a significant role after the discovery of penicillin more than 85 years ago. Since then, numerous NPs have been isolated and characterized. What mostly have fascinated NP scientists the phytochemical diversities and their complication to find out proper manifestation in treatment and management of diseases. However, throughout the ages, humans have relied on mother nature for the practice of herbal and phytonutrients treatment to fight against numerous diseases which are expanding across the world and about $80-85 \%$ or about 6 billion people worldwide trust herbal medication for the treatment of various diseases [4,5].

Plants, in particular, have been focused in the traditional medicine, dating from around 2600 BCE, recording 1000 plant-based product in Mesopotamia, which incorporate the utilization of extracted oils of Cupressus arizonica Greene, Commiphora acuminata Mattick, Cedrus libani A. Rich., Glycyrrhiza glabra L., and Papaver somniferum L. are still utilized for the treatment of common colds and coughs to swelling and parasitic diseases [6]. Egyptian pharmaceutical which is around 2900 BCE old, claims the ancient practice with regard to conventional medicine. Despite the fact that, "Ebers Papyrus" is the best-recognized record dating from $1500 \mathrm{BCE}$, enrolling more than 700 drugs, often derived from plant sources [7]. The Chinese traditional medicine has been extensively known throughout the centuries [8], with the record from around 2000 years back(1100 BCE; Wu Shi Er Bing Fang; containing 52 medicines), tailed by the herbal Shennong (100 BCE; 365 medicines) and the herbal Tang ( 659 CE; 850 medicines). However, the records of the Indian traditional medicine dates from before 5000 years (Charaka and Sushruta Samhitas hold with 341 and 395 herbal medicines separately 1000 BCE ago) [9]. On the other hand, the Romans and Greeks also added extensively to the coherent development of the use of traditional medicine in the ancient Western world (Dioscorides, a Greek physician $\sim 100 \mathrm{CE}$ ), documented the collection, storage, and proper use of traditional medicine in the then "known world." NPs that are sold as herbal and/or food supplements for medications covers half of the main 50 drugs sold in European pharmacies. Furthermore, modern pharmacopeia contains not $<25 \%$ drugs, resulting from numerous plants and many synthetic analogs that are manufactured based on the archetype or else derivatives from NPs [10]. The World Health Organization (WHO) also defined traditional medicine as: The whole of the information, abilities, and practices in light of the hypotheses, convictions, and experiences of indigenous to different cultures, whether logical or not, utilizes as a part of the support of health-care service and in addition in the prevention, identification, improvement, or treatment of physical and psychological instability [11]. Numerous traditional systems of medicine are practiced around the world with numerous related beliefs and social causes, of which the most ancient practice is traditional Indian medicine [12]. Ayurveda, the traditional Indian medicine remains the most earliest, with sound philosophical root.

Western studies have revealed that more than $40 \%$ of Americans and more than 20-60\% of Europeans utilize some form of complementary and 
alternative medicine $[5,13]$. The use of NPs as health-care management system might be displayed a great challenge in early human progress. Possibly early humans often consumed non-consumable plants, which might lead to vomiting, diarrhea, coma, or other toxic reactions - or even death. However, exchange of knowledge from generation to generation has empowered humans to perceive and make data about eatable assets and natural medicines [14]. Similarly, improvement of traditional knowledge of NPs came into existence and enlargement of information extended to generation by generation. Until the early $20^{\text {th }}$ century, the principal source of medications for drug preparations is obtained mostly from plant and vegetable sources. Extracts of plants as a source of NPs and traditional medicine have been utilized for thousands of years, and those ancient formulations are recorded in ancient literature [15]. In this way, the plant has provided man with all his needs, e.g., foods, shelters, clothing's, flavor's, fragrances, and medicines. Henceforth, plants became an integral of ancient human civilizations. In India, the history of traditional medicines and its health-care record goes back to 5000 years $\mathrm{BCE}$, when health-care needs and diseases were noted in ancient literature such as "Rigveda" (1700-1100 BCE), "Yajurveda" (1400-1000 BCE), and "Atharva Veda" (1200 BCE). Later, the manuscripts such as "Charaka Samhita" (990 BCE), "Sushruta Samhita" (660 BCE), and "Dhanwantari Nighantu" (1800 CE), where the use of plants and polyherbal formulations was emphasized and widely practiced. Fig. 1 further elaborates the ancient Indian medicinal manuscript [16].

The practice of medicines which are thought to be Indian origin or which have come to India from outside and got absorbed into Indian culture is known as traditional medicine of India, exemplified in Fig. 2. India has the exclusive distinction of its own recognized traditional medicine; Ayurveda, Siddha, Unani, Yoga and Naturopathy, and Homoeopathy. Despite the fact that Homoeopathy came to India in the $18^{\text {th }}$ century,

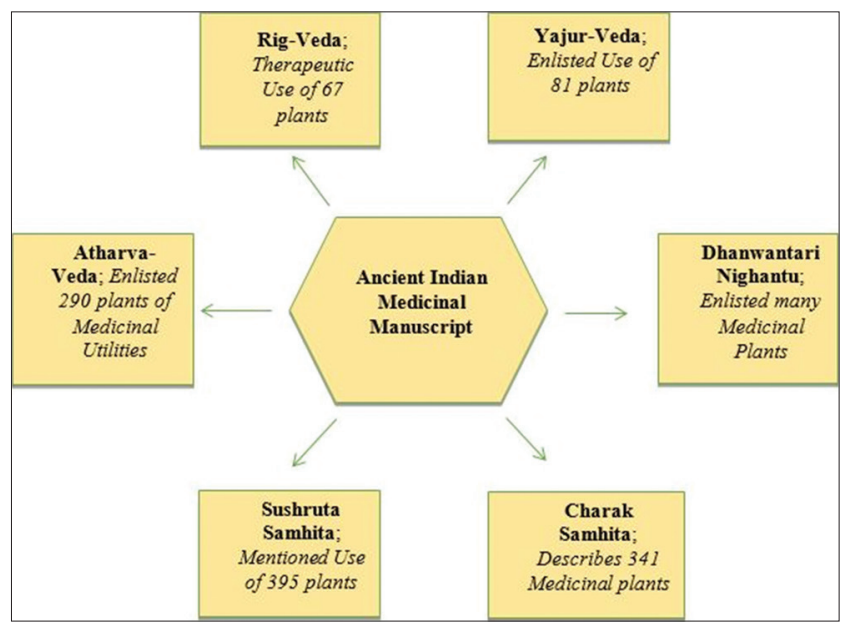

Fig. 1: Enlisted plants of the ancient Indian medicinal manuscript

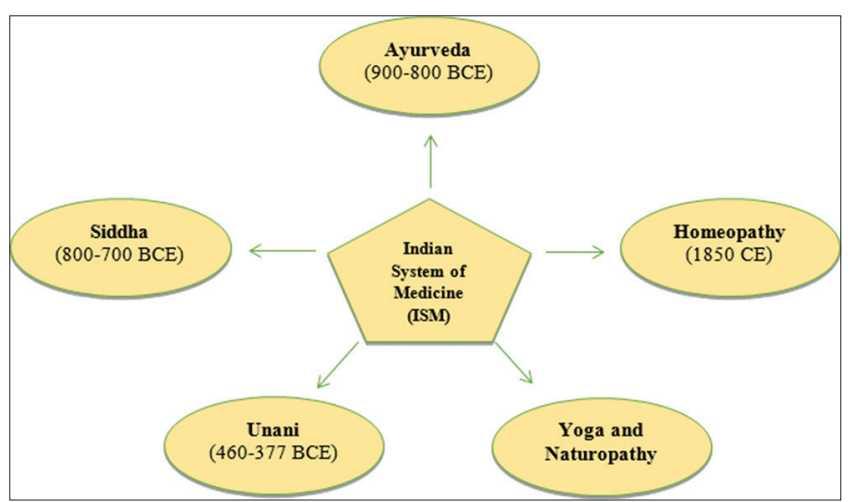

Fig. 2: Recognized systems of Indian medicinal practice but it is totally absorbed into the Indian culture and got improved like another traditional system consequently it is enriched and became a part of Indian traditional medicine [16].

\section{Ayurveda}

The literal meaning of Ayurveda is "The Science of Life;" the combination of two Sanskrit words "ayur" (life) and "veda" (science or knowledge) [17]. Ayurveda involves a logical convention of harmonious living, and its beginning can be drawn from ancient information in Rigveda and Atharva veda. The source of Ayurveda has been lost in ancient relic, yet its ideas and methodologies have been idealized in between 2500 and 500 BCE in India [18]. The utilization of natural resources for advancement through generous experimentation and experiences of day-to-day life has been a regular practice of Ayurveda of Indian people. The fundamental rule of ayurvedic treatment contains two basic parts. These are to keep the reason for illness and to make the patient more mindful about the reason for the sickness. The central objective of ayurvedic treatment is "Ayurveda deals with happy and unhappy life. It explains what is appropriate and what is inappropriate in relation to the life, as well as it measures the life expectancy and the quality of life $[19,20] . "$ It is a holistic arrangement of medical services with the idea, that the human body is a network of seven fundamental tissues ("Rasa," "Rakta," "Mansa," “Meda," "Asthi," "Majja," and "Shukra") and the waste results of the body, for example, excretion, urine, and sweat, which are derived by the five fundamental components fire, water, air, ether, and earth and three dynamic energies or functional philosophies "vata, pitta, and kapha" (Tridosha). Any unevenness or unsettling influence in these fundamental standards of the body causes disease [21,22]. Ayurveda treats a patient in general and not the sickness alone. This system of drug highlights the uniqueness of every individual with respect to social conservative status, bio-personality, biosynthetic, and physiological conditions, which may prompt a specific kind of ailment. Further, this facilitates investigation with present-day logical methodologies for tending to different human services issues. Ayurvedic preparations are frequently poly-herbal mixtures of plant and/or animal-derived products, metals, and minerals. However, ancient manuscript including modern Ayurvedic Pharmacopoeia shows the dominance of NPs than other derived products [23-26].

Research on Ayurveda, over the past few decades, through multidisciplinary platforms, has given rise to higher undertakings in this field. Various drug lead compounds are developing. Due to traditional acceptance, useful assistance, socioeconomic benefit, and easy acceptability ayurvedic medicines are popularizing throughout the globe. Quality, safety, stability, and efficiency for ayurvedic medicines are now being assured through extensive research. The increasing search for newer medicinal plants derived agents, most importantly the bioactive compounds are taking a major role in the development and management of health-care issues in India.

\section{Siddha}

Siddha system of medicine is settled since the ancient human civilization in India, around 10,000 BCE-4000 BCE. Like Ayurveda, it is developed through everyday skills of utilizing natural resources for maintaining good health and remains as an oldest medicinal practice in South India. This practice of medicine is based Saiva philosophy, one out of six branches of Hindu religion. The word "Siddha" indicates "holy harmony" or "attaining excellence" or "recognized fact" and the "Siddhars" were supernatural beings who obtain intellectual powers by constant practice of such type of medicine. Siddha system of medicine is believed to be established by 18 "Siddhars;" Thirumoolar, Ahappe, Agathiyar, Sunthara ananthar, Bogar, Machchamuni, Konganar, Korakkar, Therayar, Karuvoorar, Nandi Devar, Idaikkadar, Iraamathevar, Sattamuni, Kuthampai, Paampaatti, Aluhanna, and Kahapusundar. This medicinal practice believes preserving the human well-being is crucial to succeeding the eternal bliss and the philosophical idea includes "food is medicine, medicine is food" and "sound mind makes a sound body $[27,28]$." The philosophy and the principles of this system are similar to Ayurveda. Siddha system of medicine also reflects human 
body as an accumulation of seven basic materials, three humors and the discarded products. An equilibrium among humor reflects a healthy well-being, and its imbalance leads to disease or sickness. The physical, physiological, moral, and intellectual components describe 96 principal constituents of a human being. Alteration leads to the wrong running of 96 principles which then manifests disease [29]. Diagnosis is eight-fold including check-up of speech, pulse, complexion, tongue, etc. Sensory functions and its refinement can be achieved by yoga, by the mind, by sensory organs, and by pain and pleasure. The psychosomatic system can be re-established by administrating metals and minerals along with NPs [22].

Siddha medicines are less known toward the western world in light of the fact that a large portion of the literature is not interpreted from the Tamil language [30], but rather well recognized as an alternative biomedicine inside Tamil communities [31]. Siddha philosophy is created in the therapeutic, profound, and scholarly perspectives, it gives equal importance to the inward soul and outer body, especially identifying methods of alchemy (converting base metals into gold), urine examination, and practice materia medica are the uniqueness in comparison to ayurvedic medicines [32,28]. As of now, Siddha medicines are acknowledged as being reasonable to treat all issue expect crisis cases [33]. Likewise, herbo metal or herbo mineral preparations which certainly contain nanoparticles are more effective in chronic disorders [34,35].

\section{Unani}

The Unani system of medicine pioneered in Greece, and it was urbanized by Arabs into an elegant medical science established on the framework of the Greek philosopher and physician Hippocrates (460-377 BCE); Hippocrates (Buqrat) and Galen (Jalinoos). Greek and Arab scholars such as Galen (131-212 CE), Raazes (850-925 CE), and Avicenna (980-1037 CE) enhanced the system significantly and is known as Greco-Arab Medicine. Unani practice of medicine is built on the four conditions of living such as hot, sodden, frosty, and dry and four humors of Hippocratic hypothesis, namely, blood, yellow bile, dark bile, and mucus. Unani solution of medicine was mixed with the Indian culture in Mughal Emperors and is utilized by an extensive segment of the population in India. Unani views the human body as made up of seven standards; Mizaj (temperaments), Anza (organs), Quo (resources), Arkan (components), Arawh (spirits), Aklath (humors), and Afal (capacities). These standards oversee prosperity and additionally disease condition [36,37].

A doctor considers every one of these components before diagnosing and recommending treatment. The NP drugs utilized as a part of this framework are representative of life and are free from side effects. Such medications, which are lethal in unrefined shape, are prepared and purified before utilization [22]. Types of medications recommended in the Unani system of medicine are diet therapy, regimental treatment, and pharmaco-treatment:

1. Diet treatment goes for treating certain illnesses, by the organization of particular diet control plans or by controling the amount and nature of diet in a routine basis.

2. Regimental treatment incorporates diaphoresis, diuresis, Turkish shower, knead cleansing, etc.

3. Pharmaco-treatment manages the utilization of NPs

Unani system of medicine is a comprehensive medication where single or in the formulation, in crude form is preferred, which miraculously deals with numerous states of health and disease. This system extends great solutions for gastrointestinal, nervous disorders, and cardiovascular disease.

\section{Yoga and naturopathy}

Yoga is a Sanskrit word, composed and spoken limitedly in India. Sanskrit is popular fundamentally in mainstream Indian ceremonial settings, for example, Hinduism, Jainism, and Buddhism. The word yoga has changing interpretations yet is most usually comprehended as significance union. Yoga explores preventive and curative aptitudes as a training exercise for people to improve mindfulness. Dialectical behavior therapy has its underlying foundations in cognitive behavior therapy, a different model of mindfulness happens for cognitive therapy practices, known as care based subjective treatment [38,39].

Naturopathy is a particular type of essential drugs that balances ageold healing traditions with logical progress and current research. Naturopathy is guided by an interesting arrangement of the rule that perceives the body's inborn healing capacity, emphasizes disease prevention, and urges singular responsibility to get ideal wellbeing. Naturopathic hypothesis, the disease is seen as a procedure of disturbance to well-being and consequent recovery with regard to natural healing systems [40].

\section{Homeopathy}

The principle of Homoeopathy stays one of the most debatable therapeutic practice and been known Hippocrates from Greece around 450 BCE. The present-day practice of Homoeopathy is better recognized by a German doctor, Dr. Samuel Hahnemann (1755CE-1843CE). The word "Homoeopathy" has been derived from Greek words, "Homois" which means similar and "pathos" which means suffering. Homeopathy is a therapeutic technique utilizing arrangements of substances whose impacts when regulated to healthy individuals match to the appearances of the illness in the individual patient $[41,42]$. The methodology is believed to work on two main principles $[43,44]$ :

1. "Like cures like;" a healthy individual would manifest the same symptom with the drug, that particular drug is the cure for the same illness.

2. "Infinite dilution;" therapeutic activity is enhanced by repeated dilution and succession even when diluted beyond Avogadro's number.

Homeopathy essentially implies treating illnesses with cures, which are equipped for producing symptoms identical to the disease when taken. For example, bark extract of Cinchona officinalis, which contains quinine, if administrated by a healthy individual, would then produces exactly the same symptom than that of malaria. Homeopathic methods are polished since over 200 years in India and are now practiced throughout the world. It has mixed so well into the roots and customs of India and has been perceived as one of the recognized systems of medicine in health-care service.

Indian traditional medicine has its origin in India that evolved through a continuous process of transformation from its Vedic period and a single drug or blends in crude shape are favored over many fold formulations. In spite of the fact that the starting points and advancement times of these traditional medication process are different, however, there is a common background through this foundation, is in their basic standards and practices by utilizing the plants and plant-based preparations in the medicinal services. The extent of utilization of plants in a different system of medications appears in Fig. 3. Moreover, around 85-90\%

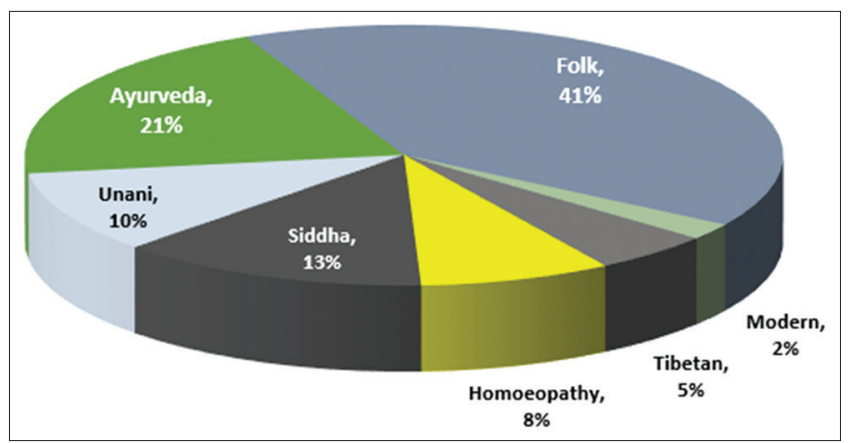

Fig. 3: Displaying the percentage of plants used in different systems of medicines in India 
Indian population depends on the traditional system for essential medicinal services.

\section{DISCUSSION}

NPs have been the source of most active ingredients in western prescriptions. This is generally acknowledged to be genuine when connected to drug discovery from NPs. In the "past days," before the progression of high-throughput screening and the post-genomic time, over $80 \%$ of drugs were obtained from NPs or motivated by natural compounds. More than $100 \mathrm{NP}$ derived compounds are now experiencing clinical trials and not $<100$ similar projects are in preclinical advancement. Most presently anticipated medications are derived from leads from plants and microbial sources [45-47]. Ethno-pharmaceutical may be defined extensively as the utilization of plants by people as drugs, yet this utilization could be called more accurately ethno-botanic medicine. Conventional medicine is an expansive term used to characterize any Non-Western therapeutic practice. Ethnopharmacology is an exceptionally expanded way to deal with to drug discovery including the perception, depiction, and test examination of indigenous medications and their biologic exercises [48,49-51].

Advancement of Ayurveda and plant-based solutions for medicinal services through everyday experiences is a part of the social legacy of India. The WHO, additionally, appraises that around $80-85 \%$ of the population living in the developing countries relies on complementary or alternative pharmaceutical for fundamental therapeutic administrations and necessities. In all the conventional frameworks of medication, the medicinal plants assume to play a noteworthy influence and constitute the backbone. It is hard to get exact figures for the aggregate number of medicinal plants on earth; as appeared by some estimation, around 35,000-70,000 plant species are being used worldwide in human health-care services, and Indian pharmacopoeia alone incorporates more than 3000 drugs of natural origin.

As showed by the WHO, estimations the populations in developing countries such as India (65-70\%), Rwanda ( 75\%), Tanzania (50$60 \%$ ), Uganda (55-60\%), Benin (80\%), and Ethiopia (90\%) widely utilize traditional and alternative medications for health-care services. NPs are an essential part of a large portion of the conventional and alternative systems of around the globe. In developed nations such as Australia (48-50\%), Belgium (30\%), France (50\%), USA (45\%), and Canada (65-70\%), a remarkable level of the population are utilizing traditional cures occasionally for human health services $[3,46,52]$. On the other hand, worldwide trade exchange of NPs is evaluated around the US $\$ 60$ billion every year and is emerging at the rate of $8 \%$ consistently. An investigation uncovers that around $42 \%$ of the bestselling pharmaceutical items in 1997 were NPs or drugs derived from NPs, worth of the US $\$ 17.5$ billion $[53,54]$.

Yet, there is a long-running debate between individuals, who utilize NP solutions for different ailments and disorders, and the individuals who depend on the present day; modern medicine for cure. The individuals who incline toward modern medicinal cures battle that with NP cures are for the most part "smoke and mirrors," and that nothing can be comprehended by consumption of NP. They trust that natural cures are generally fake treatments utilized by people who have been dishonestly educated [55-57].

However, "truth" remains "truth" under all conditions. There are a large number of trial confirmations which reveals NP cures are not fake treatments.

In 1989, in British Medical Journal the consequences of a nonindividualized, randomized, double-blind, placebo-controlled, hybrid trial on the utilization of Rhus Toxicodendron 6 C (A Homeopathic medication) in patients with essential fibromyalgia. In spite of vital takeoffs from genuine to the goodness of homeopathy, a portion of the discoveries of this examination was, The patients improved in all factors when they took dynamic medications instead of placebo. The investigation demonstrated a huge favor for the homeopathic pharmaceutical [58]. Parallel outcomes in 2004, journal, Rheumatology published individualized double-blind, placebocontrolled, randomized treatment of patients with fibromyalgia in an examination that was supported by the National Centre for Complementary and Alternative Medicine and the National Institutes of Health. The essential finding and conclusion were, members on dynamic treatment exhibited significantly more enhancements in personal satisfaction and global well-being. This investigation reproduces and expands a past 1-month placebo-controlled hybrid examination in fibromyalgia that pre-screened for just a single homeopathic treatment. The examination likewise demonstrated that individualized homeopathy is fundamentally superior to anything than placebo in diminishing tender points and enhancing the personal approval and worldwide wellbeing of people with fibromyalgia [59].

In 2013, the homeopathic pathogenetic pilot test for Hepatitis C (Hep C) nosode experiment has been led by Dr. Shah with the volunteers prepared to compose data in prescribed questionnaires and information were investigated. A fifteen-stage technique was used as a part of the planning of Hep C nosode (Genotype I and III), permitting future preparation of an indistinguishable nosode. 22 volunteers were entered, 15 got Hep C nosode in 30c potency, 7 got a placebo, and once per week for a month. The conclusion was that "an enhanced technique for nosode preparation utilized for a doubleblind, randomized placebo-controlled pathogenetic trial of the Hep $\mathrm{C}$ nosode produced indications, which may encourage its remedy. The nosode ought to be additionally investigated for the treatment of immunologically mediated illnesses, diseases including Hep C, fibrotic pathology, and chronic inflammatory disorders [60]. Pediatrics published the outcome of a Randomized Controlled Trials treatment in children with the looseness of the bowels in Nicaragua. The treatment group had a statistically significant decrease in duration of looseness of the bowels $(p<0.05)$ and the quantity of stool every day between the two groups after $72 \mathrm{~h}$ of treatment $(\mathrm{p}<0.05)$ [61]. There are innumerable confirmations which propose the herbals drugs cure the illnesses for many centuries and are affordable, ready-to-use for health-care services. Yet, Western medicine was dominated during the British period despite the strength and public faith in these systems of medicine, after the foundation of $1^{\text {st }}$ Asian Medical College and Hospital, Kolkata in 1835, the ancestral Indian traditional system became an alternative system of medicinal practice in India. The Medical College and Hospital, Kolkata in Fig. 4, frequently referred to as Calcutta Medical College, is a hospital and medical teaching institution in the Indian city Kolkata in the territory of West Bengal.

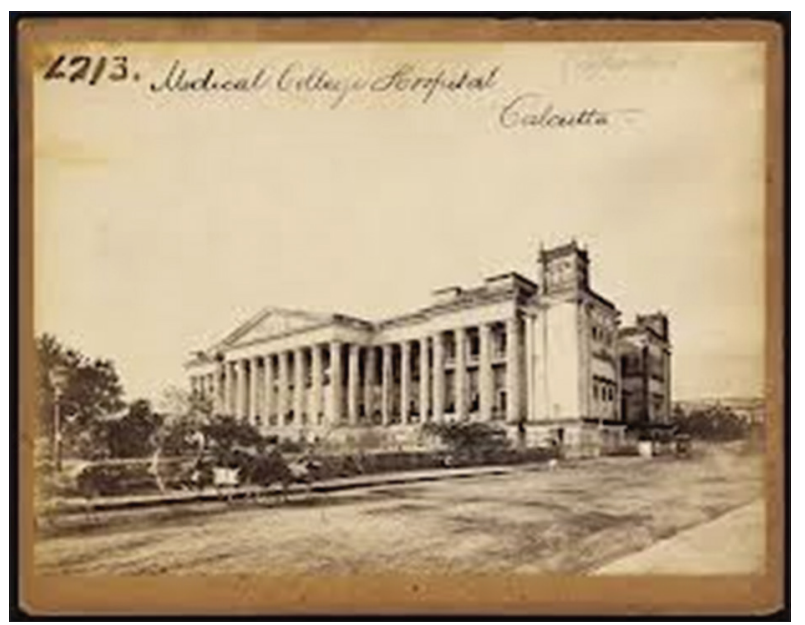

Fig. 4: Medical College Hospital Calcutta (Kolkata) - mid $19^{\text {th }}$ century 
Photographer: Francis Frith

Whole-plate albumen print from wet collodion glass negative. Source: http://www.oldindianphotos.in/2010/06/medical-collegehospital calcutta.htm

The medical college was built up in 1835. Instantly, after this establishment on January 28, 1835 was trailed by Madras Medical College on February 2, 1835. Medicinal College, Bengal was the central therapeutic foundation in India bestowing a deliberate training in the western pharmaceutical [62].

Despite the fact that, 5000-year-old, Indian traditional medicine, had to face the greatest misfortune when Lord Macaulay settled the argument about whether India should support traditional medicines or western medicines. According to his choice, western medicines should solely cultivate in all zones administered by East India Company. In this manner, Indian traditional medicine was effectively disheartened, and the Western solution was perceived as the main legitimate system of medicine to be taken after $[63,64]$.

However, nowadays, many modern medical practitioners are realizing and starting to recommend alternative (natural) remedies to their patients when modern medicines do not work, it is also because natural remedies have less or no side effects, are less dangerous for prolong use, rather than allopathic synthesized medicines; those endorse toxic side effects and may sometimes lead to death. Conversely, there is a developing confirmation to demonstrate that ingredients of NPs act synergistically which may neutralize side effects in the proper blend. The civil argument between modern medicine and traditional medicines comes down to a basic truth; each person, regardless of education or sickness, ought to be educated about the actualities concerning their illness and the associated side effects of medicines [55].

\section{CONCLUSION}

Therapeutic knowledge of Indian traditional medicine has propelled various traditional approaches with similar or different theories and methodologies, which are of regional significance. After independence, in 1951, planning commission took birth. Much later, in 1995, a different department called Department of Indian System of Medicine and Homoeopathy (ISM\&H) was molded. The acronym, AYUSH, which stands for Ayurveda, Yoga and Naturopathy, Unani, Siddha, and Homoeopathy was the new name of ISM\&H in 2003 as a detached Department under Ministry of Health and Family Welfare, Government of India. Due to mastery of current pharmaceuticals notwithstanding open confidence and trust, Indian traditional medicines are in inimical hindrances. A need has developed to join the entire whole traditional medicinal system and systematize it with an extremely strong optimistic approach in spreading our own medical tradition is the need of great importance. Consequently, phytochemical and biochemical research with a continuous endeavor for the revival and spreading of Indian medical inheritance for the welfare of the society at large is needed.

\section{REFERENCES}

1. Bhanot A, Sharma R, Noolvi MN. Natural sources as potential anticancer agents: A review. Int J Phytomed 2011;3:9-26.

2. Demain AL. Importance of microbial natural products and the need to revitalize their discovery. J Ind Microbiol Biotechnol 2014;41:185-201.

3. Katz L, Baltz RH. Natural product discovery: Past, present, and future. $\mathrm{J}$ Ind Microbiol Biotechnol 2016;43:155-76.

4. World Health Organization. WHO Guidelines on Safety Monitoring of Herbal Medicines in Pharmacovigilance Systems. WHO; 2004.

5. Ekor M. The growing use of herbal medicines: Issues relating to adverse reactions and challenges in monitoring safety. Front Pharmacol 2014:4:177.

6. Cragg GM, Newman DJ. Natural products: A continuing source of novel drug leads. Biochim Biophys Acta 2013;1830:3670-95.

7. Borchardt JK. The beginnings of drug therapy: Ancient mesopotamian medicine. Drug News Perspect 2002;15:187-92.

8. Huang KC. The Pharmacology of Chinese Herbs. $2^{\text {nd }}$ ed. Boca Raton, FL: CRC Press; 1999.
9. Dev S. Ancient-modern concordance in ayurvedic plants: Some examples. In: Development of Plant-Based Medicines: Conservation, Efficacy and Safety. Dordrecht: Springer Netherlands; 2001. p. 47-67.

10. Ringler C, Willenbockel D, Perez N, Rosegrant M, Zhu T, Matthews N. Global linkages among energy, food and water: An economic assessment. J Environ Stud Sci 2016;6:161-71.

11. WHO. General Guidelines for Methodologies on Research and Evaluation of Traditional Medicine World Health Organization. Vol. 1. World Health Organization; 2000. p. 1-5.

12. Wah HL, Ramchurn K, Alladin SB. Metal levels in traditional Chinese and ayurvedic medicines. In: Chemistry: The Key to Our Sustainable Future. Dordrecht: Springer Netherlands; 2014. p. 321-37.

13. Lim MK, Sadarangani P, Chan HL, Heng JY. Complementary and alternative medicine use in multiracial Singapore. Complement Ther Med 2005:13:16-24.

14. Yuan H, Ma Q, Ye L, Piao G. The traditional medicine and modern medicine from natural products. Molecules 2016;21:559.

15. Madari H, Jacobs RS. An analysis of cytotoxic botanical formulations used in the traditional medicine of ancient Persia as abortifacients. J Nat Prod 2004:67:1204-10.

16. Kumar B, Vijayakumar M, Govindarajan R, Pushpangadan P. Ethno pharmacological approaches to wound healing - Exploring medicinal plants of India. J Ethnopharmacol 2007;114:103-13.

17. Prasad LV. Indian system of medicine and homoeopathy. In: Chaudhury RR, Rafei UM, editors. Traditional Medicine in Asia. New Delhi: WHO-Regional Office for South East Asia; 2002. p. 283-6.

18. Mukherjee PK. Evaluation of Indian Traditional Medicine. Drug Inf J 2001;35:623-32.

19. Singh LK. Indian Cultural Heritage Perspective for Tourism. Delhi: Gyan Publishing House; 2008.

20. Mukherjee PK, Harwansh RK, Bahadur S, Kar A, Ahmmed SK, Pulok KM, et al. Development of ayurveda-tradition to trend. J Ethnopharmacol 2017;197:10-24

21. Lad VS. Fundamental Principles of Ayurveda. Albuquerque, New Mexico: The Ayurvedic Press; 2002. p. 25-9.

22. Mukherjee PK, Wahile A. Integrated approaches towards drug development from ayurveda and other Indian system of medicines. J Ethnopharmacol 2006;103:25-35.

23. Ayurvedic Pharmacopoeia of India. Government of India, Ministry of Health and Family Welfare. Part I. Vol. I. New Delhi, India: Department of Indian Systems of Medicine and Homoeopathy; 2001.

24. Ayurvedic Pharmacopoeia of India. Government of India, Ministry of Health and Family Welfare. Part I. Vol. II. New Delhi, India: Department of Indian Systems of Medicine and Homoeopathy; 2001a.

25. Ayurvedic Pharmacopoeia of India. Government of India, Ministry of Health and Family Welfare. Part I. Vol. III. New Delhi, India: Department of Indian Systems of Medicine and Homoeopathy; 2001b.

26. Ayurvedic Formulary of India. Government of India, Ministry of Health and Family Welfare. Part II. New Delhi, India: Department of Indian Systems of Medicine and Homoeopathy; 2000

27. Piet JH. A Logical Presentation of the Śaiva Siddhānta Philosophy (Doctoral Dissertation, Christian Literature Society for India (United Society for Christian Literature); 1952.

28. Sathasivampillai SV, Rajamanoharan PR, Munday M, Heinrich M. Plants used to treat diabetes in Sri Lankan siddha medicine - An ethno pharmacological review of historical and modern sources. J Ethnopharmacol 2017;198:531-99.

29. Pillai NK. History of Siddha Medicine. Chennai, India: Department of Indian Medicine and Homeopathy; 1998. p. 33-5.

30. Thas JJ. Siddha medicine - Background and principles and the application for skin diseases. Clin Dermatol 2008;26:62-78.

31. Stephen ES. Complementary and alternative medicine. Harrisons Principles of Internal Medicine. 16 $6^{\text {th }}$ ed. USA: McGraw-Hill Medical; 2005.

32. Narayanaswamy V. In: Pandit SS, editor. Introduction to the Siddha System of Medicine. T. Nagar, Madras (Chennai): Anandam Research Institute of Siddha Medicine; 1975.

33. AYUSH (The Department of Ayurveda, Yoga and Naturopathy, Unani, Siddha, and Homoeopathy) Siddha; 2010. Available from: http://www. indianmedicine.nic.in/index2. asp?slid=36\&sublinkid=23\&lang=1

34. ISM (Indian Systems of Medicine, Government of Kerala), About Siddha; 2011. Available from: http://www.ism.kerala.gov.in/index.php/ about-sidha.html.

35. Husain A, Sofi GD, Tajuddin DR, Kumar N. Unani system of medicine introduction and challenges. Med J Islam World Acad Sci 2010;18:27-30.

36. Kalim MD, Bhattacharyya D, Banerjee A, Chattopadhyay S. Oxidative 
DNA damage preventive activity and antioxidant potential of plants used in Unani system of medicine. BMC Complement Altern Med 2010;10:77

37. Chopra D, Simon D. The Seven Spiritual Laws of Yoga: A Practical Guide to Healing Body, Mind, and Spirit. Hoboken, NJ: John Wiley \& Sons; 2004.

38. Gordon T. Theorizing Yoga as a Mindfulness Skill. Procedia Soc Behav Sci 2013;84:1224-7.

39. Fleming SA, Gutknecht NC. Naturopathy and the primary care practice. Prim Care 2010;37:119-36.

40. Grabia S, Ernst E. Homeopathic aggravations: A systematic review of randomised, placebo-controlled clinical trials. Homeopathy 2003;92:92-8

41. Ernst E. Anthroposophical medicine: A systematic review of randomised clinical trials. Wien Klin Wochenschr 2004;116:128-30.

42. Ernst E. Homoeopathy: Past, present and future. Br J Clin Pharmacol 2003;44:435-7.

43. Linde K, Clausius N, Ramirez G, Melchart D, Eitel F, Hedges LV, et al. Are the clinical effects of homeopathy placebo effects? A meta-analysis of placebo-controlled trials. Lancet 1997;350:834-43.

44. Baker DD, Chu M, Oza U, Rajgarhia V. The value of natural products to future pharmaceutical discovery. Nat Prod Rep 2007;24:1225-44.

45. Alamgir AN. Therapeutic use of Medicinal Plants and their Extracts: Volume 1: Pharmacognosy. Vol. 73. Switzerland: Springer; 2017.

46. Fabricant DS, Farnsworth NR. The value of plants used in traditional medicine for drug discovery. Environ Health Perspect 2001;109:69-75.

47. WHO. WHO traditional medicine strategy 2002-2005. World Health Organization Document. Geneva: WHO/EDM/TRM/2002.1, World Health Organization; 2002.

48. Kate KT, Laird SA. Biodiversity and business: Coming to terms with the grand bargain. Int Aff 2000;76:241-64.

49. Torri MC, Herrmann TM. Traditional ethno biological knowledge and bioprospecting. In: Bridges between Tradition and Innovation in Ethno Medicine. Dordrecht: Springer Netherlands; 2011. p. 43-84.

50. Mukherjee PK, Venkatesh P, Ponnusankar S. Ethnopharmacology and integrative medicine - Let the history tell the future. J Ayurveda Integr Med 2010;1:100-9.

51. Fisher P, Greenwood A, Huskisson EC, Turner P, Belon P. Effect of homeopathic treatment on fibrositis (primary fibromyalgia). BMJ 1989;299:365
52. Bell IR, Lewis DA $2^{\text {nd }}$, Brooks AJ, Schwartz GE, Lewis SE, Walsh BT, et al. Improved clinical status in fibromyalgia patients treated with individualized homeopathic remedies versus placebo. Rheumatology (Oxford) 2004;43:577-82

53. Shah R. Hepatitis C nosode: The preparation and homeopathic pathogen etic trial. Homeopathy 2013;102:207-14

54. Jacobs J, Gloyd SS, Gale JL, Jiménez LM, Crothers D. Treatment of acute childhood diarrhea with homeopathic medicine: A randomized clinical trial in Nicaragua. Pediatrics 1994;93:719-25.

55. Das A, Sen S. A History of the Calcutta Medical College and Hospital, 1835-1936. Delhi: Pearson Education India; 2011. p. 477-522.

56. Department of Indian System of Medicine and Homoepathy. National Policy on ISM and H-2002. New Delhi: Ministry of Health and Family Welfare, Government of India; 2002.

57. AYUSH in India. Planning and Evaluation Cell, Ministry of Ayurveda, Yoga and Naturopathy, Unani, Siddha and Homoeopathy (AYUSH). New Delhi: Government of India; 2014.

58. Sinha T, Ahmaruzzaman M, Adhikari PP, Bora R. Green and environmentally sustainable fabrication of $\mathrm{Ag}-\mathrm{SnO} 2$ nan composite and its multifunctional efficacy as photocatalyst and antibacterial and antioxidant agent. ACS Sustainable Chem Eng 2017;5:4645-55.

59. Adhikari PP, Paul SB, Choudhury MD, Choudhury S. GC-MS Studies on the steam-distillate of the medicinally important plant Cleome gynandra L. Int J Appl Res Stud 2017;3:568-74.

60. Adhikari PP, Talukdar S, Borah A. Ethnomedicobotanical study of indigenous knowledge on medicinal plants used for the treatment of reproductive problems in Nalbari district, Assam, India. J Ethnopharmacol 2017;210:381

61. Paul SB, Choudhury S, Adhikari PP. Isolated chemical components from spider weed, Cleome gynandra Linn.: An overview. Assam Univ J Sci Technol 2012;10:166-73.

62. Manikandaselvi S, Vadivel V, Brindha P. Review on ethnobotanical studies of nutraceutical plant: Capparis spinosa L. (Caper). Asian J Pharm Clin Res 2016;9:21-4

63. Anttonen H, Husman P, Hussi T, Leino T, Ylikoski M. Proceedings of of the International Conference. Towar Better Work Well-Being; 2010. p. 135

64. Das A, Ahmed AB. Natural permeation enhancer for transdermal drug delivery system and permeation evaluation : A review. Asian J Pharm Clin Res 2017;10:7-11. 